\title{
Synthesis of Nanoparticles Using Euphorbia prostrata Extract Reveals a Shift from Apoptosis to G0/G1 Arrest in Leishmania donovani
}

 \\ Mohana Roopan ${ }^{3}$, Abdul Abdul Rahuman ${ }^{1 *}$ and Neeloo Singh ${ }^{2 *}$ \\ ${ }^{1}$ Unit of Nanotechnology and Bioactive Natural Products, Post Graduate and Research Department of Zoology, C. Abdul Hakeem College, Melvisharam-632509, Vellore \\ District, Tamil Nadu, India \\ ${ }^{2}$ Biochemistry Division, CSIR Central Drug Research Institute, Jankipuram Extension, Sitapur Road, Lucknow- 226031, India \\ ${ }^{3}$ Organic \& Medicinal Chemistry Research Laboratory, Organic Chemistry Division, School of Advanced Sciences, VIT University, Vellore-632 014, Tamil Nadu, India \\ ${ }^{4}$ Transmission Electron Microscopy, CSIR Indian Institute of Toxicology Research, M.G. Marg Lucknow-226001, India

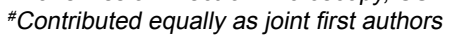

\begin{abstract}
The aim of the present investigation was to synthesize silver $(\mathrm{Ag})$ and titanium dioxide $\left(\mathrm{TiO}_{2}\right)$ nanoparticles (NPs) using the aqueous leaves extract of Euphorbia prostrata as antileishmanial agents and to explore the mechanism of induced cell death. In vitro antileishmanial activity of synthesized NPs was tested against promastigotes of Leishmania donovani by alamar Blue ${ }^{\circledR}$ cell viability reagent and propidium iodide uptake assay. The effective leishmanicidal activity of synthesized Ag NPs was further confirmed by cell cycle progression, externalized phosphatidylserine, DNA fragmentation assay, reactive oxygen species (ROS) level, intracellular non-protein thiols and transmission electron microscopy (TEM) of the treated parasites. TEM analysis of the synthesized Ag NPs and $\mathrm{TiO}_{2} \mathrm{NPs}$ showed spherical shape with an average size of $12.82 \pm 2.50$ and $83.22 \pm 1.50 \mathrm{~nm}$, respectively. Ag NPs was found to be the most active agent against Leishmania parasites after $24 \mathrm{~h}$ exposure with $\mathrm{IC}_{50}$ value of $14.94 \mu \mathrm{g} / \mathrm{mL}$. A significant increase in $\mathrm{G} 0 /$ $\mathrm{G} 1$ phase of the cell cycle with subsequent decrease in $\mathrm{S}$ and $\mathrm{G} 2 / \mathrm{M}$ phases was observed when compared to control and thus confirming the growth inhibitory effect of synthesized Ag NPs. Decreased ROS level was also observed which could be responsible for caspase independent shift from apoptosis (G0/G1 arrest) to massive necrosis. High molecular weight DNA fragmentation as a positive consequence of necrotic cell death was also visualized. In the present study, the unique trypanothione/trypanothione reductase (TR) system of Leishmania cells was significantly inhibited by synthesized Ag NPs was reported. The green synthesized Ag NPs may provide promising leads for the development of cost effective and safer alternative treatment against visceral leishmaniasis.
\end{abstract}

Keywords: Euphorbia prostrata; Synthesized nanoparticles; Leishmania donovani; Cell cycle arrest; Trypanothione reductase; Transmission electron microscopy; Chemotherapy

\section{Introduction}

Neglected diseases caused by parasites are the second cause of mortality and impose a substantial burden of morbidity round the globe and more predominantly in the developing countries. Leishmaniasis currently threatens 350 million people in 88 countries around the world. Two million new cases are considered to occur annually, with an estimated 12 million people presently infected [1]. Among different leishmanial infections, Visceral leishmaniasis (VL) caused by Leishmania donovani is the most threatening parasite. Although miltefosine and amphotericin $\mathrm{B}$ are used for clinical treatment, the antileishmanial drug arsenal still requires improvement [2]. For instance, miltefosine monotherapy has failed to cure relapsing VL in HIV-infected patients and thus its role against the HIV-associated VL remains unclear [3].

Nanomedicine is defining the use of nanotechnology in medicine, which has been of great interest in recent years. The use of nanoparticles (NPs) for therapeutics is one of the purposes of nanomedicine [4,5]. In recent years, an increasing percentage of nanomaterials are emerging and making advancement in different fields. NPs play an indispensable role in drug delivery, diagnostics, imaging, sensing, gene delivery, artificial implants and tissue engineering [6]. Sinha et al. [7] have reported that the biosynthesis of NPs is advantageous over chemical and physical methods as it is a cost-effective and environment friendly method, where it is not necessary to use high pressure, energy, temperature and toxic chemicals. Silver nanoparticles (Ag NPs) have several important applications in the field of biolabelling, sensors, antimicrobial agents and filters. They are capable of purifying drinking water, degrading pesticides and killing human pathogenic bacteria [8]. Ag NPs have been used in treatment and improvement of drug delivery against leishmaniasis [9-12]. Silver polypyridyl complexes are biologically active against Leishmania mexicana, where they interact with DNA [13]. Similarly, nano-preparations with titanium dioxide nanoparticles $\left(\mathrm{TiO}_{2} \mathrm{NPs}\right)$ are currently under investigation as novel treatments for acne vulgaris, recurrent condyloma accuminata, atopic dermatitis, hyperpigmented skin lesions and other non dermatologic diseases [14]. Recent authors investigated that the Quercetin (polyphenolic compound) conjugated gold NPs were evaluated against promastigotes and amastigotes of L. donovani [15].

There are limited studies concerning the green synthesis of NPs and its control efficacy against Leishmania parasite. Among the various

*Corresponding authors: Abdul Abdul Rahuman, Unit of Nanotechnology and Bioactive Natural Products, Post Graduate and Research Department of Zoology, C. Abdul Hakeem College, Melvisharam-632509, Vellore District Tamil Nadu, India, Tel: +91-9442310155; Fax: +91-041-72269487; E-mail: abdulrahuman6@hotmail.com

Neeloo Singh, Unit of Nanotechnology and Bioactive Natural Products, Post Graduate and Research Department of Zoology, C. Abdul Hakeem College Melvisharam-632509, Vellore District, Tamil Nadu, India, Tel: +91-9415002065 Fax: +91-522-22623405; E-mail: neeloo888@yahoo.com

Received June 12, 2014; Accepted July 25, 2014; Published July 30, 2014

Citation: Zahir AA, Chauhan IS, Bagavan A, Kamaraj C, Elango G, et al. (2014) Synthesis of Nanoparticles Using Euphorbia prostrata Extract Reveals a Shift from Apoptosis to G0/G1 Arrest in Leishmania donovani. J Nanomed Nanotechnol 5: 213. doi: $10.4172 / 2157-7439.1000213$

Copyright: $\odot 2014$ Zahir AA, et al. This is an open-access article distributed under the terms of the Creative Commons Attribution License, which permits unrestricted use, distribution, and reproduction in any medium, provided the original author and source are credited. 
biosynthetic approaches, the use of plant extracts is preferable as they are easily available, safe to handle and possess a broad viability of metabolites. The potential of plants as biological materials for the synthesis of NPs is yet to be fully explored [16]. Euphorbia prostrata is a small, prostrate and hispidly pubescent annual herb found all over India. The leaves extract of $E$. prostrata showed antibacterial, nematicidal and antiparasitic activities [17]. Anthraquinones, flavonoids, phenols, phlobotannins, polysaccharides, saponins, tannins and terpenoids were isolated from the leaves extract of E. prostrata [18]. The flavonoids were promising compounds for controlling human and animal parasitic diseases [19]. Phenolic compounds were tested against Leishmania spp. and for immunomodulatory effects on macrophage [20]. Similarly, the antileishmanial activities of terpenoid derivatives were tested against promastigotes and intracellular amastigotes form of $L$. donovani [21]. In the present study, the antileishmanial activity of green synthesized Ag NPs and $\mathrm{TiO}_{2}$ NPs using the aqueous leaves extract of $E$. prostrata were evaluated against promastigotes of $L$. donovani.

\section{Materials and Methods}

$\mathrm{AgNO}_{3}$ and $\mathrm{TiO}(\mathrm{OH})_{2}$ analytical grade were purchased from Qualigens Fine Chemicals, Mumbai, India (99.9\% pure) and Himedia Laboratories Pvt. Ltd., Mumbai, India, respectively. AlamarBlue cell viability reagent, 2',7- dichlorohydrofluorescein diacetate (DCFHDA) and 5-chloromethylfluorescein-diacetate (cellTracker ${ }^{\mathrm{TM}}$ Green CMFDA) were purchased from Invitrogen, Carisbad, CA. Sodium cacodylate and araldite-DDSA mixture were acquired from Ladd Research Industries, USA. Propidium iodide (PI) and RNAse A were purchased from Sigma-Aldrich (St. Louis, MO, USA) and Fermentas (Waltham, MA, USA), respectively. All other chemicals and reagents were obtained from Sigma-Aldrich with high purity analytical grade.

\section{Synthesis of $\mathrm{Ag} \mathrm{NPs}$ and $\mathrm{TiO}_{2} \mathrm{NPs}$}

Fresh leaves of E. prostrata were collected in and around Melvisharam, Vellore district, Tamil Nadu, India. The aqueous leaves extract was prepared by taking $2 \mathrm{~g}$ of finely cut leaves in $250 \mathrm{~mL}$ of Erlenmeyer flask along with $100 \mathrm{~mL}$ of sterilized double distilled water and boiling the mixture at $60^{\circ} \mathrm{C}$ for $15-20 \mathrm{~min}$. The extract was filtered with Whatman filter paper no. 1 , stored at $-20^{\circ} \mathrm{C}$ and used within a week. The biosynthesis of Ag NPs was carried out using different compositions of the aqueous leaves extract with $\mathrm{AgNO}_{3}$ solution (3:97, 6:94, 9:91, 12:88 and 15:85 mL). The reaction mixture was periodically observed for the change in color and analyzed by UV-Vis spectrophotometer in the range of $100-700 \mathrm{~nm}$. Total volume of $88 \mathrm{~mL}$ of $1 \mathrm{mM} \mathrm{AgNO}$ solution was reduced using $12 \mathrm{~mL}$ of aqueous leaves extract of $E$. prostrata at room temperature for $6 \mathrm{~h}$, resulting in a brown yellow colored solution indicating the formation of Ag NPs synthesis [22]. For synthesis of $\mathrm{TiO}_{2}$ NPs, the Erlenmeyer flask containing 100 $\mathrm{mL}$ of $5 \mathrm{mM} \mathrm{TiO}(\mathrm{OH})_{2}$ was stirred for $2 \mathrm{~h}$. Different concentrations of aqueous leaves extract of $E$. prostrata were prepared and interacted with the $\mathrm{TiO}(\mathrm{OH})_{2}$ solution mixing ratio of 5:95, 10:90, 15:85, 20:80 and $25: 75 \mathrm{~mL}$, separately. $20 \mathrm{~mL}$ of aqueous leaves extract of E. prostrata was added to $80 \mathrm{~mL}$ of $\mathrm{TiO}(\mathrm{OH})_{2}$ solution for the optimization of $\mathrm{TiO}_{2}$ NPs synthesis. The pure $\mathrm{TiO}(\mathrm{OH})_{2}$, solution and the aqueous leaves extract didn't show any color change. Whereas in the leaves extract with $\mathrm{TiO}(\mathrm{OH})_{2}$, showed the change of color to light green. Different reaction parameters (concentrations of plant extract, substrate concentrations, $\mathrm{pH}$, temperature and reaction time) were optimized to synthesize NPs with controlled properties [23].

\section{Characterization of synthesized $\mathrm{Ag}$ NPs and $\mathrm{TiO}_{2} \mathrm{NPs}$}

Synthesis of NPs solution with leaves extract was observed by
UV-Vis spectroscopy. The bioreduction of ions in the solutions was monitored by periodic sampling of aliquots $(1 \mathrm{~mL})$ of the aqueous component after 20 times dilution and measured in the UV-Vis spectra. Samples were monitored as a function of time of reaction using Shimadzu 1601 spectrophotometer in the $100-700 \mathrm{~nm}$ range operated at a resolution of $1 \mathrm{~nm}$. The reduced solution centrifuged at $8000 \mathrm{rpm}$ for $40 \mathrm{~min}$ and resulting supernatant was discarded and pellet obtained was redispersed in deionized water. Centrifugation was repeated three to five times to wash off any adsorbed substances on the surface of the synthesized NPs.

Thus obtained purified and dried pellet of synthesized Ag NPs and $\mathrm{TiO}_{2}$ NPs were subjected to X-ray diffraction (XRD) analysis. For XRD studies, dried NPs were coated on XRD grid, and the spectra were recorded by using Phillips PW 1830 instrument operating at a voltage of $40 \mathrm{kV}$ and a current of $30 \mathrm{~mA}$ with $\mathrm{Cu} \mathrm{Kal}$ radiation. Fourier transform infrared (FTIR) analysis of the samples were carried out using Perkin Elmer spectrophotometer in the diffuse reflectance mode at a resolution of $4 \mathrm{~cm}^{-1}$ in $\mathrm{KBr}$ pellets and showed possible functional groups for the formation of NPs. Topography of synthesized NPs was studied using AFM analysis (Atomic force microscopy -Veeco Innova, USA). Images have been processed using XEI software given by Park system. The synthesized NPs were examined using Innova advanced scanning probe microscope (CP-II, Veeco Instruments Inc., USA) in a non-contact tapping mode. A thin film of the sample was prepared on a glass slide by dropping $100 \mu \mathrm{L}$ of the sample on the slide, and allowed to dry for $5 \mathrm{~min}$. Topographical images were obtained in non-contact mode using silicon nitride tips at a resonance frequency of $218 \mathrm{kHz}$ in ambient air by oscillating the cantilever assembly at or near the cantilever's resonant frequency using a piezoelectric crystal. Characterization was done by observing the patterns on the surface topography and data analysis through WSXM software [24]. The size of the NPs was confirmed by using TEM analysis (Transmission electron microscopy - Hitachi H-7100) using an accelerating voltage of $120 \mathrm{kV}$ and methanol as solvent.

\section{Gas chromatography-mass spectrometry (GC-MS) analysis}

The chemical composition of aqueous leaves extract of E. prostrata was analyzed using GC-MS (GCD-HP1800A system, Hewlett-Packard, USA) equipped with a split/split less capillary injection port. For GCMS detection, an electron ionization system (quadruples analyzer; mass range, 10-425 amu) with ionization energy of $70 \mathrm{eV}$ was used. Each of these steps carried out under high vacuum from $10^{-4}$ to $10^{-8}$ torr. Helium gas was used as a carrier at a constant flow rate of $1 \mathrm{~mL} /$ min. Injector and mass transfer line temperatures were set at $250^{\circ} \mathrm{C}$ and $280^{\circ} \mathrm{C}$, respectively. The components of aqueous leaves extract of $E$. prostrata were identified after comparison with the available data in library (NIST) attached to the GC-MS instrument and reported [25].

\section{Parasite culture and analysis of cell viability}

Promastigotes of $L$. donovani strain (MHOM/IN/80/DD8) were routinely cultured as described previously [26]. AlamarBlue cell viability reagent was used for evaluation of antileishmanial activity of synthesized Ag NPs. Logarithmic phase promastigotes of L. donovani (50,000 cells, final volume $200 \mu \mathrm{L} /$ well $)$ were seeded in 96 well microtiter plates (Greiner, bio-one, Germany) in the presence of different concentrations $(0,12.5,25,50$ and $100 \mu \mathrm{g} / \mathrm{mL})$ of synthesized Ag NPs and incubated at $25^{\circ} \mathrm{C}$ for $24 \mathrm{~h}$. Miltefosine was used as the standard drug. $20 \mu \mathrm{L}$ of AlamarBlue was added to each well and the plate was further incubated at $25^{\circ} \mathrm{C}$ for $4 \mathrm{~h}$. Absorbance was measured in a ELISA reader (Biotek Instruments, Epoch) using $\lambda=570 \mathrm{~nm}$ as test wavelength 
(resorufin) and $\lambda=600 \mathrm{~nm}$ as reference wavelength (resazurin) serving as blank. The oxidized form of AlamarBlue resazurin (non-toxic, cell permeable and blue in colour) was reduced by metabolically active cells to resorufin (highly fluorescent, red in colour). Percentage growth inhibition of promastigotes treated with synthesized Ag NPs was analyzed by the following formula [27].

Percentage growth inhibition $=$ Untreated control $\lambda(570-600 \mathrm{~nm})$ - treated set $\lambda(570-600 \mathrm{~nm}) /$ untreated control $\lambda(570-600 \mathrm{~nm}) X 100$.

In vitro antileishmanial activity was expressed as the concentration inhibiting parasite growth by $50 \%$ (IC50) and was analyzed by plotting percentage growth inhibition versus $\log$ growth concentration $(0,12.5$, 25, 50 and $100 \mu \mathrm{g} / \mathrm{mL}$ ) of synthesized Ag NPs.

\section{Transmission electron microscopy}

TEM analysis was carried out to observe the ultrastructural changes of the morphology of $L$. donovani promastigotes induced by synthesized Ag NPs. Parasites were incubated in the presence of synthesized Ag NPs at $\mathrm{IC}_{50}$ dose for $45 \mathrm{~min}$, washed with PBS (pH 7.2) prior to fixing in $2.5 \%$ glutraldehyde in sodium cacodylate buffer ( $\mathrm{pH}$ 7.2 ) for $2 \mathrm{~h}$ at $4^{\circ} \mathrm{C}$. Fixed parasites were centrifuged at $2000 \mathrm{rpm}$ for 10 min and washed 3 times with $0.1 \mathrm{M}$ sodium cacodylate buffer and post fixed in $1 \%$ osmium tetraoxide for $2 \mathrm{~h}$. Post fixed parasites were washed with sodium cacodylate and dehydrated in ascending acetone series $(15,30,60$ and $100 \%)$, embedded in araldite-DDSA mixture and baked at $60^{\circ} \mathrm{C}$ for $48 \mathrm{~h}$. After baking blocks were cut (60-80 nm thick) by an ultramicrotome (Leica EM UC7, Vienna, Austria), mounted on copper grids and double stained with uranyl acetate and lead citrate. Analysis of stained sections were examined by TEM (TECNAI G2 SPIRIT, FEI, Netherland) equipped with Gatan Orius camera at $80 \mathrm{KV}$ [28].

\section{Propidium iodide uptake assay}

Logarithmic phase promastigotes of $L$. donovani $\left(1 \times 10^{6}\right.$ cells, final volume $2 \mathrm{~mL} /$ well) were seeded in 6 well microtiter plates (Greiner, bio-one, Germany) in the presence of different concentrations (12.5, 25 and $50 \mu \mathrm{g} / \mathrm{mL}$ ) of synthesized Ag NPs and incubated at $25^{\circ} \mathrm{C}$ for 24 h. After indicated incubation times cells were centrifuged $(2000 \mathrm{rpm}$ for $10 \mathrm{~min}$ ), washed once with PBS (pH 7.2), resuspended in $50 \mu \mathrm{g} / \mathrm{mL}$ final concentration of PI, and incubated for $30 \mathrm{~min}$ in the dark at room temperature. Unbound PI was removed by washing and samples were processed on a FACSCalibur flow cytometer (BD Bioscience, San Jose, CA, USA) and analysed using CellQuest Pro software.

\section{Cell cycle analysis}

Briefly $2 \times 10^{6}$ cells $/ \mathrm{mL} \log$ phase $L$. donovani promastigotes were treated with different concentrations $(12.5,25$ and $50 \mu \mathrm{g} / \mathrm{mL})$ of synthesized Ag NPs for $24 \mathrm{~h}$ and were harvested by centrifugation at $2000 \mathrm{rpm}$ for $5 \mathrm{~min}$ at $4^{\circ} \mathrm{C}$. Cells were washed once in $1 \mathrm{~mL}$ PBS and then fixed by incubation in $70 \%$ ethanol: $30 \%$ PBS for $1 \mathrm{~h}$ at $4{ }^{\circ} \mathrm{C}$. Fixed cells were harvested by centrifugation at $1000 \mathrm{rpm}$ for $10 \mathrm{~min}$ at $4^{\circ} \mathrm{C}$, washed in $1 \mathrm{~mL}$ PBS and resuspended in $1 \mathrm{~mL}$ PBS with RNAse A $(100 \mu \mathrm{g} / \mathrm{mL})$ and PI $(10 \mu \mathrm{g} / \mathrm{mL})$. The cells were incubated at room temperature for $45 \mathrm{~min}$ and then analysed using FACSCalibur flow cytometer (BD Bioscience, San Jose, CA, USA). Cell cycle distribution was modeled using ModFit LT for Mac V3.0 [29].

\section{Analysis of externalized phosphatidylserine}

To quantify the percentage of parasites undergoing apoptosis, annexin-V-FITC and necrosis, PI dual staining was performed as per the manufacturer's instructions (AnnexinV-FITC Apoptosis detection kit, Sigma, MO, USA). In brief $2 \times 10^{6}$ cells $/ \mathrm{mL} \log$ phase $L$. donovani promastigotes were treated with different concentrations $(12.5,25$ and $50 \mu \mathrm{g} / \mathrm{mL}$ ) of synthesized Ag NPs for $24 \mathrm{~h}$ and cells were centrifuged (2000 rpm for $5 \mathrm{~min}$ ), washed twice in PBS and resuspended in annexin $\mathrm{V}$ binding buffer $[10 \mathrm{mM}$ Hepes/ $\mathrm{NaOH}$ (pH 7.4), $140 \mathrm{mM} \mathrm{NaCl}$ and $2.5 \mathrm{mM} \mathrm{CaCl}_{2}$ ]. Annexin V-FITC and PI were then added according to the manufacturer's instructions and incubated for $15 \mathrm{~min}$ in the dark at $20-25^{\circ} \mathrm{C}$. Samples were analyzed on a FACSCalibur flow cytometer and 10,000 events from each sample were acquired to ensure adequate data [29].

\section{DNA fragmentation assay}

The fragmentation of DNA into nucleosomal bands, as a function of apoptotic cell death was studied by DNA laddering assay as described previously [29]. Total cellular DNA from promastigotes exposed to different concentrations $(12.5,25$ and $50 \mu \mathrm{g} / \mathrm{mL})$ of synthesized Ag NPs was isolated according to manufacturer's instructions (Apoptotic DNA ladder detection kit, Cat. No. KHO1021, Molecular Probes, USA). The isolated DNA was quantified spectrophotometrically by the absorbance ratio of $260 / 280 \mathrm{~nm}$ and DNA ( $1 \mu \mathrm{g} / \mathrm{lane}$ ) was separated on $1.2 \%$ agarose gel containing ethidium bromide in TBE buffer $(50 \mathrm{mM} ; \mathrm{pH}$ 8.0) for $1.5 \mathrm{~h}$ at $75 \mathrm{~V}$, visualized under UV light and photographed using a gel documentation system (Genei ${ }^{\mathrm{TM}}$, Uvitech, Cambridge).

\section{Measurement of reactive oxygen species (ROS) level}

Intracellular ROS level was measured in L. donovani promastigotes as described previously [30]. Briefly, $2 \times 10^{6}$ cells $/ \mathrm{mL} \log$ phase $L$. donovani promastigotes treated with different concentrations of synthesized Ag NPs $(12.5,25$ and $50 \mu \mathrm{g} / \mathrm{mL})$ for $24 \mathrm{~h}$ were washed and resuspended in $500 \mu \mathrm{L}$ of medium M-199 and loaded with the cell permeant probe 2,7-dichlorodihydrofluorescein diacetate ( $\left.\mathrm{H}_{2} \mathrm{DCFDA}\right)$ $(10 \mu \mathrm{M})$ for $30 \mathrm{~min}$ at $20-25^{\circ} \mathrm{C}$, and fluorescence was monitored. The fluorescent probe $\mathrm{H}_{2} \mathrm{DCFDA}$ is one of the most widely used techniques for direct measuring of the redox state of a cell. It is a cell permeable and relatively non-fluorescent molecule. It is also extremely sensitive to the changes in the redox state of a cell and can be used to follow the changes of ROS over time. Activity of cellular esterases cleaves $\mathrm{H}_{2}$ DCFDA into 2,7-dichlorodihydrofluorescein $\left(\mathrm{DCFH}_{2}\right)$. Peroxidases, cytochrome $\mathrm{c}$ and $\mathrm{Fe}^{2+}$ can all oxidize $\mathrm{DCFH}_{2}$ to 2, 7-dichlorofluorescein (DCF) in the presence of hydrogen peroxide. Accumulation of DCF in the cells was measured by an increase in fluorescence at $530 \mathrm{~nm}$ when the sample was excited at $485 \mathrm{~nm}$. Fluorescence at $530 \mathrm{~nm}$ was measured using a FACSCalibur flow cytometer (BD Bioscience) and analysed using CellQuest Pro software. It is assumed to be proportional to the concentration of hydrogen peroxide in the cells [29].

\section{Measurement of intracellular non-protein thiols}

The probe, 5-chloromethylfluorescein-diacetate (CMFH-DA, Sigma) is a cell permeable, non-fluorescent dye that upon entering the cell, rapidly binds with non-protein thiols and becomes non-permeable; the simultaneous cleavage of the diacetate moiety by cellular esterases yields a fluorescent thioether. Accordingly, the detected fluorescence is directly proportional to the amount of intracellular non-protein thiols [31]. $2 \times 10^{6}$ cells $/ \mathrm{mL} \log$ phase of $L$. donovani promastigotes treated with aqueous leaves extract of E. prostrata, synthesized Ag $\mathrm{NPs}$ and $\mathrm{AgNO}_{3}$ solution for $24 \mathrm{~h}$ were collected into $1.5 \mathrm{~mL}$ micro centrifuge tubes and centrifuged at $700 \mathrm{rpm}$ for $5 \mathrm{~min}$ to remove the supernatant. Then the cell pellets were washed with PBS, incubated with 5-chloromethylfluorescein-diacetate in the dark for $15 \mathrm{~min}$ at $37^{\circ} \mathrm{C}$ and analyzed for fluorescence in the FL1 channel, equipped with a 
$530 / 30 \mathrm{~nm}$ band pass filter by using FACSCalibur flow cytometer (BD Bioscience) and analysed by CellQuest Pro software.

\section{Statistical analysis}

The data has been summarized in mean \pm SD. The comparison of group has been done by one way analysis of variance. The groups are compared by Dunnett's test after one way annova. The individual comparison has been done New man/Keuls test. $\mathrm{p}=0.05$ has been considered as the level of significance.

\section{Results and Discussion}

The green leaves of E. prostrata were selected for synthesis of NPs because they are the site of photosynthesis and availability of more $\mathrm{H}^{+}$ions to reduce $\mathrm{AgNO}_{3}$ and $\mathrm{TiO}(\mathrm{OH})_{2}$ into $\mathrm{Ag} \mathrm{NPs}$ and $\mathrm{TiO}_{2}$ NPs, respectively. The leaves extract of E. prostrata was mixed in the aqueous solution of the silver ion complex and it started to change the color from watery to brown due to reduction of silver ion which indicated the formation of Ag NPs. NPs formation was monitored by colour change, despite the fact that colour change has been reported to be the initial evidence of NPs formation [23]. Results of the present study revealed that the overall optimized reaction conditions for the synthesis of Ag NPs were: concentration of aqueous leaves extract $=12$ $\mathrm{mL}$, concentration of $\mathrm{AgNO}_{3}$ solution $=88 \mathrm{~mL}$ of $1 \mathrm{mM}$, temperature $=$ $45^{\circ} \mathrm{C}, \mathrm{pH}=9.0$, time $=6 \mathrm{~h}$ and the maximum absorption peaks observed at $420 \mathrm{~nm}$. Similarly, synthesized $\mathrm{TiO}_{2}$ NPs were: concentration of aqueous leaves extract $=20 \mathrm{~mL}$, concentration of $\mathrm{TiO}(\mathrm{OH})_{2}$, solution $=80 \mathrm{~mL}$ of $5 \mathrm{mM}$, temperature $=40^{\circ} \mathrm{C}, \mathrm{pH}=8.0$, time $=10 \mathrm{~h}$ and the maximum absorption peak observed at $305 \mathrm{~nm}$. These results are in good agreement with the previous authors report [23].

\section{Characterization of the synthesized NPs}

The synthesized Ag NPs using E. prostrata leaves extract was supported by X-ray diffraction measurements. XRD spectrum was compared with the standard confirmed spectrum of Ag particles formed in the present experiments, which were in the form of nanocrystals, as evidenced by the peaks at $2 \theta$ values of $38.26^{\circ}, 44.45^{\circ}, 64.58^{\circ}$ and $77.49^{\circ}$ which were indexed to the planes 111,200, 220 and 311, respectively. The average grain size of Ag NPs formed in the biosynthesis was determined to be $12.82 \pm 2.5 \mathrm{~nm}$ for the higher intense peak using
Scherrer's formula, $d=0.89 \lambda / \beta \cos \theta$. XRD analysis for the synthesized $\mathrm{TiO}_{2} \mathrm{NPs}$ showed distinct diffraction peaks at $27.63^{\circ}, 36.27^{\circ}, 41.43^{\circ}$, $54.49^{\circ}, 56.80^{\circ}$ and $69.16^{\circ}$ indexed to the planes $110,101,111,211,220$ and 301 , respectively (Figure 1). The average grain size of $\mathrm{TiO}_{2} \mathrm{NPs}$ formed in the biosynthesis was determined to be $83.22 \pm 1.50 \mathrm{~nm}$. The sharp peaks and absence of unidentified peaks confirmed the crystallinity and higher purity of prepared NPs. Dubey et al. [32] reported that the size of nano silver as estimated from the full width at half maximum of the (111) peak of silver using the Scherrer formula was $20-80 \mathrm{~nm}$. XRD peaks at $2 \theta$ value of $25.25^{\circ}$ (101) confirm the characteristic facets for anatase form of $\mathrm{TiO}_{2}$ [33]. This estimation confirmed the hypothesis of particle monocrystallinity. The sharpening of the peaks clearly indicates that the particles were in the nanoregime.

The FTIR spectroscopy is used to probe the chemical composition of the surface and capping agents for the synthesis of NPs. FTIR analysis of synthesized $\mathrm{Ag}$ NPs and $\mathrm{TiO}_{2} \mathrm{NPs}$ using the aqueous leaves extract of $E$. prostrata are shown in Figure 2. The synthesized Ag NPs showed the presence of bands due to heterocyclic amine, $\mathrm{NH}$ stretch $\left(3431 \mathrm{~cm}^{-1}\right)$, methylene $\mathrm{C}-\mathrm{H}$ bend $\left(1616 \mathrm{~cm}^{-1}\right)$, gem-dimethyl $\left(1381 \mathrm{~cm}^{-1}\right)$, cyclohexane ring vibrations $\left(1045 \mathrm{~cm}^{-1}\right)$, skeletal C-C vibrations $\left(818 \mathrm{~cm}^{-1}\right)$ and aliphatic iodo compounds, C-I stretch (509 $\left.\mathrm{cm}^{-1}\right)$. The functional groups for E. prostrata leaves aqueous extract and synthesized Ag NPs were 548 and $509 \mathrm{~cm}^{-1}$ for aliphatic iodo compounds, C-I stretch. Hence, it proves that synthesized Ag NPs have been synthesized with plants compounds involved in the biological reduction of the $\mathrm{AgNO}_{3}$. Similarly, the synthesized $\mathrm{TiO}_{2} \mathrm{NPs}$ showed the presence of bands due to hydroxy group, $\mathrm{H}$-bonded $\mathrm{OH}$ stretch $\left(3420 \mathrm{~cm}^{-1}\right)$, methylene C-H asym./sym. stretch $\left(2926 \mathrm{~cm}^{-1}\right)$, secondary amine, $\mathrm{NH}$ bend $\left(1618 \mathrm{~cm}^{-1}\right)$, phenol or tertiary alcohol, $\mathrm{OH}$ bend $\left(1377 \mathrm{~cm}^{-1}\right)$, cyclic ethers of large rings, C-O stretch $\left(1071 \mathrm{~cm}^{-1}\right)$ and thioethers, $\mathrm{CH}_{3}-\mathrm{S}-$, C-S stretch $\left(649 \mathrm{~cm}^{-1}\right)$. The functional groups of leaves extract and synthesized $\mathrm{TiO}_{2} \mathrm{NPs}$ were 2924 and $2926 \mathrm{~cm}^{-1}$ for methylene C-H asym./sym. stretch, 1618 and $1618 \mathrm{~cm}^{-1}$ for secondary amine, $\mathrm{NH}$ bend. After reduction of $\mathrm{TiO}(\mathrm{OH})_{2}$ the increase in intensity at $2926 \mathrm{~cm}^{-1}$ signify the involvement of the around for methylene $\mathrm{C}-\mathrm{H}$ asym./sym in the reduction process. Hence, it proves that synthesized $\mathrm{TiO}_{2}$ NPs have been synthesized with $E$. prostrata compounds involved in the biological reduction of the $\mathrm{TiO}_{2}[34]$.

The synthesized NPs were characterized by AFM for its detail size,
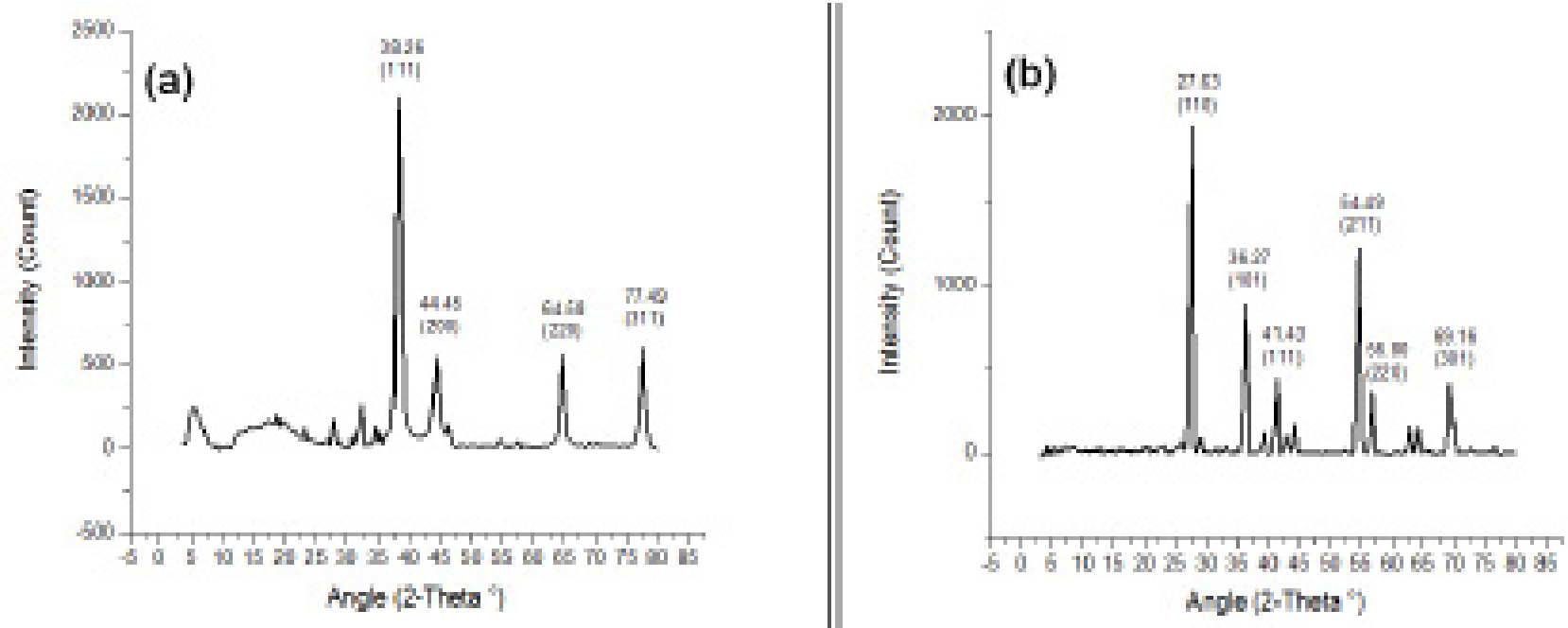

Figure 1: XRD pattern of synthesized nanoparticles using the aqueous leaves extract of $E$. prostrata (a) $\mathrm{Ag} \mathrm{NPs}_{\text {(b) }} \mathrm{TiO}_{2} \mathrm{NPs}_{\text {. }}$ 

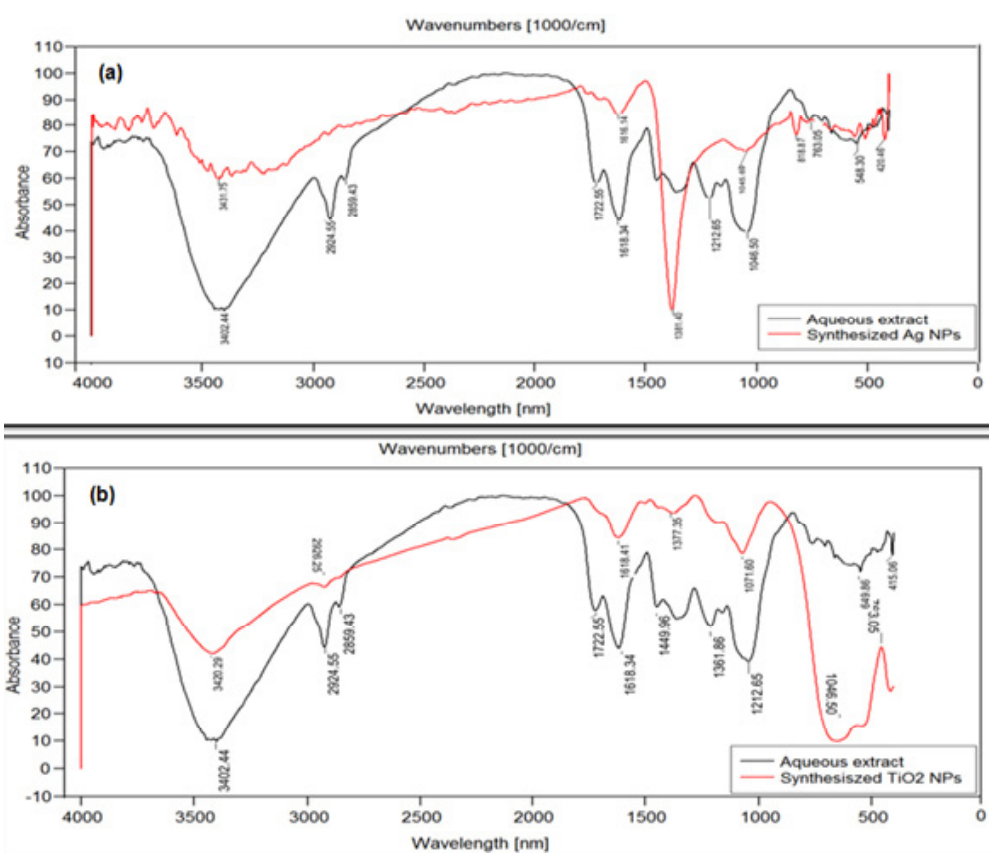

Figure 2: FTIR spectra of vacuum dried powder of synthesized nanoparticles from E. prostrata (a) Ag NPs (b) $\mathrm{TiO}_{2} \mathrm{NPs}_{\text {. }}$
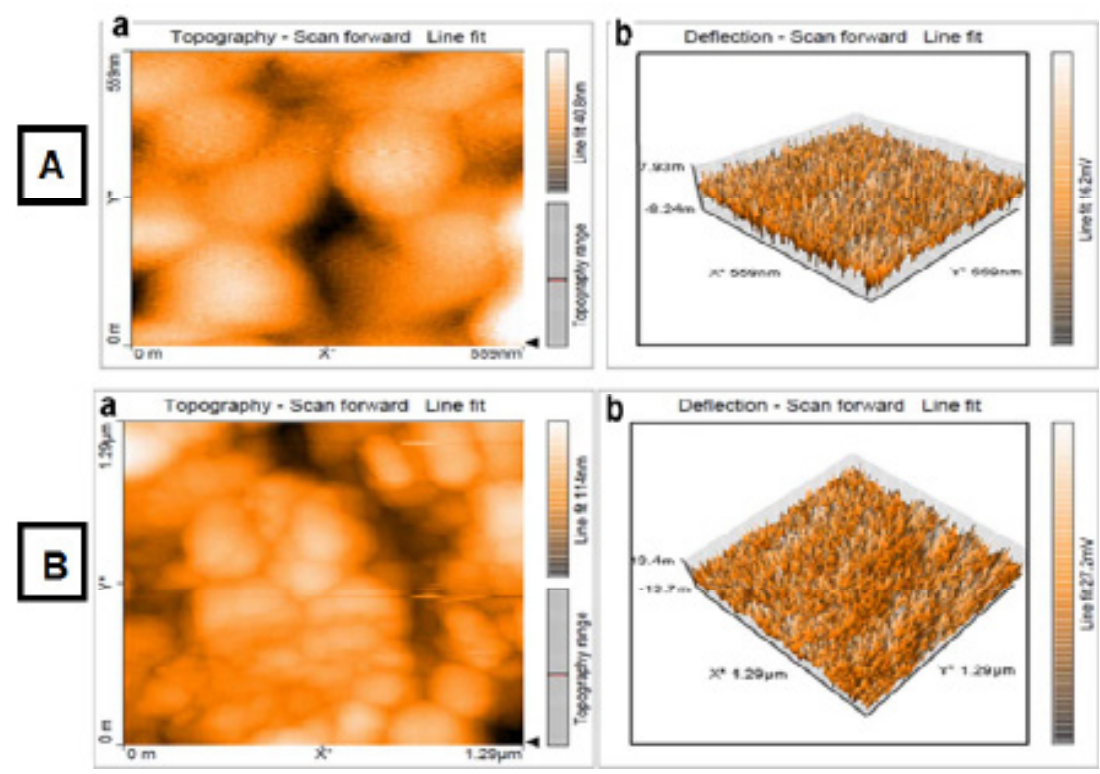

Figure 3: AFM images of the synthesized nanoparticles showing (a) increased surface view and (b) three-dimensional view (A) Ag NPs (B) TiO ${ }_{2} \mathrm{NPs}_{\text {. }}$

morphology and agglomeration. Characterization of the synthesized NPs using AFM offered a three-dimensional visualization. The uneven surface morphology was explained by the presence of both individual and agglomerated NPs. The strong crystalline nature was observed in the form of diagonal formations with ridges (Figure 3). In accordance with the present results, previous studies have demonstrated that the topographical images of irregular shaped synthesized NPs [35]. TEM images of the synthesized $\mathrm{Ag} \mathrm{NPs}$ and $\mathrm{TiO}_{2} \mathrm{NPs}$ obtained were spherical, quite polydisperse and individual particles showed an average size of $12.82 \pm 2.50$ and $83.22 \pm 1.50 \mathrm{~nm}$, respectively. SAED pattern of the $\mathrm{Ag}$ NPs, the ring-like diffraction pattern indicates that the particles were crystalline. The diffraction rings were indexed on the basis of the fcc structure of silver. Four rings arise due to reflections from (111), (200), (220) and (311) lattice planes of fcc silver, respectively. SAED pattern of the $\mathrm{TiO}_{2} \mathrm{NPs}$, six rings arise due to reflections from (110), (101), (111), (211), (220) and (301) lattice planes of fcc titanium, respectively. This is evident by sharp Braggs reflection observed in the XRD spectrum (Figure 4).

\section{GC-MS analysis}

The compounds identified by the GC-MS analysis, the retention time (RT) and percentage peak of the individual compounds in the 
Citation: Zahir AA, Chauhan IS, Bagavan A, Kamaraj C, Elango G, et al. (2014) Synthesis of Nanoparticles Using Euphorbia prostrata Extract Reveals a Shift from Apoptosis to GO/G1 Arrest in Leishmania donovani. J Nanomed Nanotechnol 5: 213. doi: 10.4172/2157-7439.1000213

Page 6 of 12

aqueous leaves extracts of E. prostrata are shown in Table 1. Four compounds were detected in the aqueous leaves extract, the major chemical constituent was identified as 2,3-dihydrobenzofuran (peak area 27.44\%) which could have acted as a reducing and capping agent for the synthesis of $\mathrm{Ag}$ NPs and $\mathrm{TiO}_{2} \mathrm{NPs}$. The other constituents such as 1,3-dihydroisobenzofuran (19.97\%), 4-choloro2,5- dimethoxybenzamine $(21.80 \%)$ and methyl 3-(hydroxymethyl) bicycle [3.2.1] oct-6-ene-1-carboxylate (5.53\%) were identified. The chemotherapeutic value of our experimental medicinal plant extract E. prostrata is also evident from an earlier study [17]. Previous studies proved that the synthetic dihydrobenzofuran lignans and related benzofurans showed promising antileishmanial compound against $L$. donovani [36].

\section{Analysis of cell viability}

Considering the efficacy of drugs available for the treatment of VL as well as their side effects and the resistance developed by parasites, the research in phytosciences, mainly regarding the properties of bioactive phytocompounds found in the crude extracts of medicinal plants, may lead to the discovery of new medicines with appropriate efficiency which are cheap and safe to the patients. Hence the purpose of this research was to study the antileishmanial effects of synthesized $\mathrm{Ag} \mathrm{NPs}$ and $\mathrm{TiO}_{2} \mathrm{NPs}$ against $L$. donovani parasites. The results showed that the synthesized Ag NPs were most active against promastigotes of L. donovani compared to aqueous leaves extract of E. prostrata, $\mathrm{AgNO}_{3}$ and $\mathrm{TiO}(\mathrm{OH})_{2}$, solutions and synthesized $\mathrm{TiO}_{2} \mathrm{NPs}_{\text {. Significance level }}$ were estimated by one way ANOVA followed by Dunnett's multiple comparison test and found to be highly significant $(\mathrm{p}<0.001)$ for synthesized Ag NPs (Table 2). Decreased mobility of promastigotes treated with aqueous leaves extract of $E$. prostrata, synthesized Ag $\mathrm{NPs}$ and $\mathrm{AgNO}_{3}$ solution were observed under light microscope in the first $24 \mathrm{~h}$ of treatment. Pronounced morphological changes within the parasite such as round to oval, shape decrease in size with dense cytoplasm and enlarged nuclei were also observed. Soon after $24 \mathrm{~h}$, the morphology of the treated promastigotes was completely destroyed.
The $\mathrm{IC}_{50}$ values were determined at $24 \mathrm{~h}$ of treatment with synthesized Ag NPs. The result showed the $\mathrm{IC}_{50} \log$ value of $1.17 \mu \mathrm{g} / \mathrm{mL}$ which is equivalent to $14.94 \mu \mathrm{g} / \mathrm{mL}$ (Figure 5). Previous studies proved that the Ag NPs demonstrated significant antileishmanial effects by inhibiting

\begin{tabular}{|c|c|c|c|c|c|}
\hline RT & Identified molecules & $\begin{array}{l}\text { Chemical } \\
\text { structure }\end{array}$ & MF & MW & $\begin{array}{c}\text { Peak } \\
\text { area \% }\end{array}$ \\
\hline 3.3 & 2,3- dihydrobenzofuran & & $\mathrm{C}_{8} \mathrm{H}_{8} \mathrm{O}$ & 120 & 27.44 \\
\hline 4.3 & $\begin{array}{l}\text { 1,3- dihydro } \\
\text { isobenzofuran }\end{array}$ & & $\mathrm{C}_{8} \mathrm{H}_{8} \mathrm{O}$ & 120 & 19.97 \\
\hline 18.5 & $\begin{array}{l}\text { 4- cholro-2,5- } \\
\text { dimethoxybenzamine }\end{array}$ & & $\mathrm{C}_{9} \mathrm{H}_{10} \mathrm{CINO}_{2}$ & 187 & 21.80 \\
\hline 22.6 & $\begin{array}{l}\text { Methyl 3-(hydromethyl) } \\
\text { bicycle [3.2.1]oct-6- } \\
\text { ene-1-carboxylate }\end{array}$ & & $\mathrm{C}_{10} \mathrm{H}_{14} \mathrm{O}_{3}$ & 182 & 5.53 \\
\hline
\end{tabular}

RT: Retention time; MF: Molecular formula; MW: Molecular weight.

Table 1: Chemical composition of the E. prostrata leaves extract identified by GCMS.

\begin{tabular}{|l|c|c|c|}
\hline \multicolumn{1}{|c|}{ Factor } & Mean & Standard deviation & p-value \\
\hline $\mathrm{Ag} \mathrm{NPs}$ & 0.255 & 0.015 & $\mathrm{p}<0.001$ \\
\hline $\mathrm{TiO}_{2} \mathrm{NPs}$ & 0.653 & 0.001 & $\mathrm{p}<0.001$ \\
\hline Aqueous extract & 0.359 & 0.007 & $\mathrm{p}<0.001$ \\
\hline $\mathrm{AgNO}_{3}$ & 0.320 & 0.003 & $\mathrm{p}<0.01$ \\
\hline $\mathrm{TiO} \mathrm{OH})_{2}$ & 0.747 & 0.018 & $\mathrm{p}<0.001$ \\
\hline Control & 0.989 & 0.016 & $\mathrm{p}<0.001$ \\
\hline
\end{tabular}

The significance between synthesized $\mathrm{Ag}$ NPs and aqueous leaves extract of E. prostrata, $\mathrm{AgNO}_{3}$, and $\mathrm{TiO}(\mathrm{OH})_{2}$ solutions and synthesized $\mathrm{TiO}_{2} \mathrm{NPs}$ (Factor). Lowest percentage cell viability was found with synthesized Ag NPs. It was significantly lower than all other factor.

Table 2: The mean \% cell viability test by one way ANOVA and Dunnett's multiple comparison test.

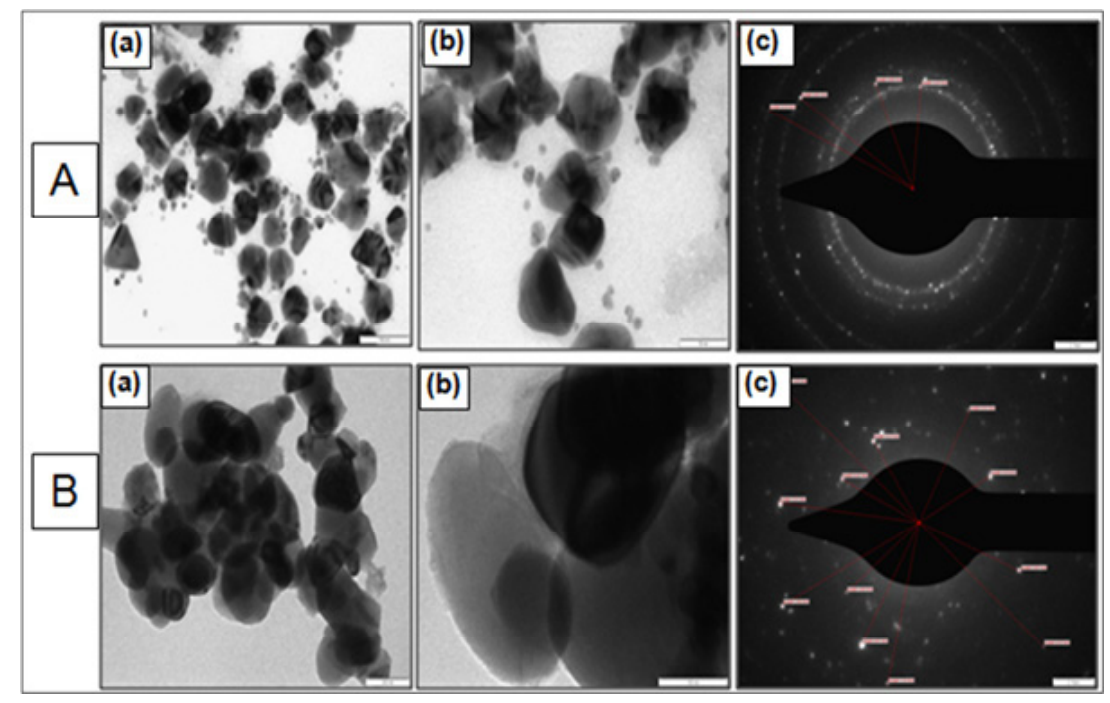

Figure 4: (A) TEM micrograph of the synthesized Ag NPs formed with $12.82 \pm 2.5 \mathrm{~nm}$ using $12 \mathrm{~mL}$ aqueous leaves extract of $E$. prostrata mixed with $88 \mathrm{~mL}$ of 1 $\mathrm{mM}$ aqueous $\mathrm{AgNO}_{3}$ solution at $45^{\circ} \mathrm{C}$ and pH 9 at two different magnification (a) $100 \mathrm{~nm}$ (b) $50 \mathrm{~nm}$ and (c) Selected area electron diffraction of the Ag NPs showed four rings arise due to reflections from (111), (200), (220) and (311) lattice planes of fcc silver, respectively (B) TEM micrograph of the synthesized TiO ${ }_{2}$ NPs formed with $83.22 \pm 1.5 \mathrm{~nm}$ using $20 \mathrm{~mL}$ aqueous leaves extract of $E$. prostrata mixed with $80 \mathrm{~mL}$ of $5 \mathrm{mM} \mathrm{TiO}(\mathrm{OH})_{2}$ solution at $45^{\circ} \mathrm{C}$ and pH 8 at different magnification (a) $200 \mathrm{~nm}$ (b) $100 \mathrm{~nm}$ and (c) Selected area electron diffraction pattern of $\mathrm{TiO}_{2}$ NPs showed six rings arise due to reflections from (110), (101), (111), (211), (220) and (301) lattice planes of fcc titanium, respectively. 
Citation: Zahir AA, Chauhan IS, Bagavan A, Kamaraj C, Elango G, et al. (2014) Synthesis of Nanoparticles Using Euphorbia prostrata Extract Reveals a Shift from Apoptosis to G0/G1 Arrest in Leishmania donovani. J Nanomed Nanotechnol 5: 213. doi: 10.4172/2157-7439.1000213

Page 7 of 12

the proliferation and metabolic activity of promastigotes form of $L$. tropica under UV light [11].

\section{Transmission electron microscopy}

The TEM study has been the most widely used techniques to visualize agglomerated NPs in cells. The ultrastructural analysis of the promastigotes treated with synthesized Ag NPs showed cytolysis with features of necrosis including a general cell hydration causing swelling of the organelles (endoplasmic reticulum and mitochondria), vacuolization, and gross alterations in the organization of the nuclear and chromatin when compared to control (Figure 6). Asharani et al. [37] reported that the Ag NPs are also known to accumulate heavily within mitochondria and are reported to impair mitochondrial function via oxidative stress.

\section{Propidium iodide uptake assay}

Cytotoxicity of different concentrations of synthesized Ag NPs was evaluated by measuring cellular uptake of PI in $L$. donovani promastigotes
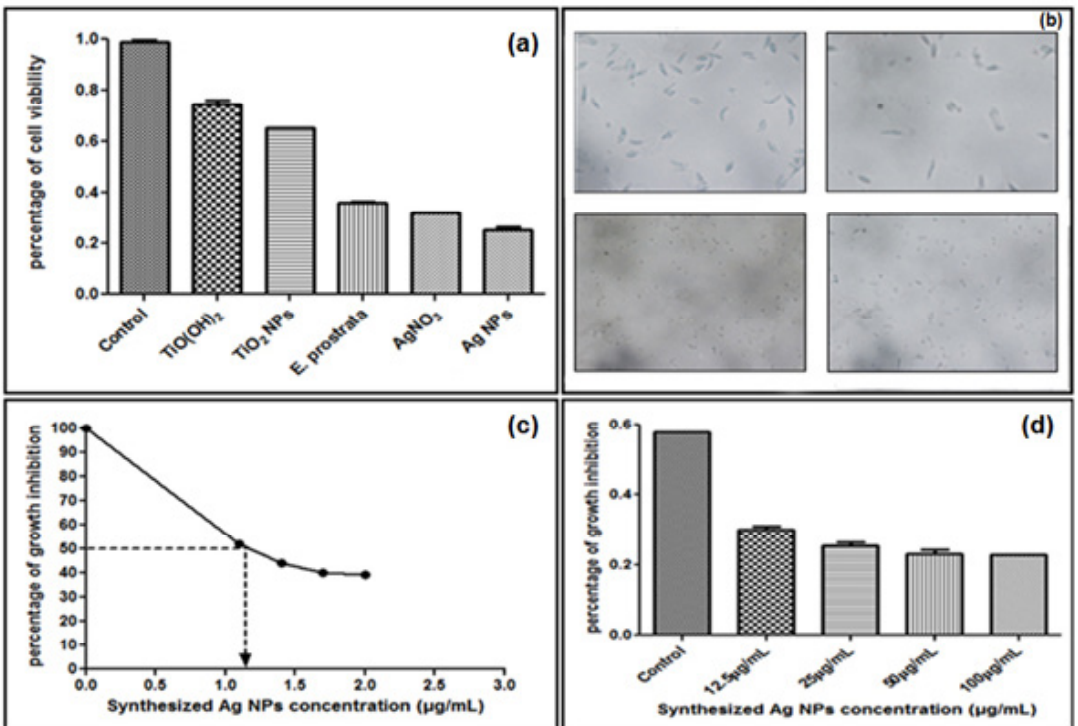

Figure 5: Cell viability assessment by alamarBlue ${ }^{\circledR}$ shows reduction in viability with different concentrations $(0,25,50$ and $100 \mu g / m L)$ of synthesized $\mathrm{Ag}$ NPs treated promastigotes (a) Graph shows that the synthesized Ag NPs were most active against promastigotes of $L$. donovani compared to aqueous leaves extract, $\mathrm{AgNO}_{3}$ and $\mathrm{TiO}(\mathrm{OH})_{2}$ solutions and synthesized $\mathrm{TiO}_{2} \mathrm{NPs}$ (b) Microscopic images of wild type promastigotes and promastigotes treated with aqueous leaves extract of $E$. prostrata $\mathrm{AgNO}$ solution and synthesized Ag NPs at a magnification of $60 \mathrm{X}$ (c) Percentage growth inhibition against log value of synthesized Ag NPs concentrations $(\mu \mathrm{g} / \mathrm{mL}), I_{50}=14.94 \mu \mathrm{g} / \mathrm{mL}$ (d) Percentage growth inhibition of $L$. donovani promastigotes treated with synthesized Ag NPs concentrations. The data are presented as means \pm standard deviation of three independent experiments.
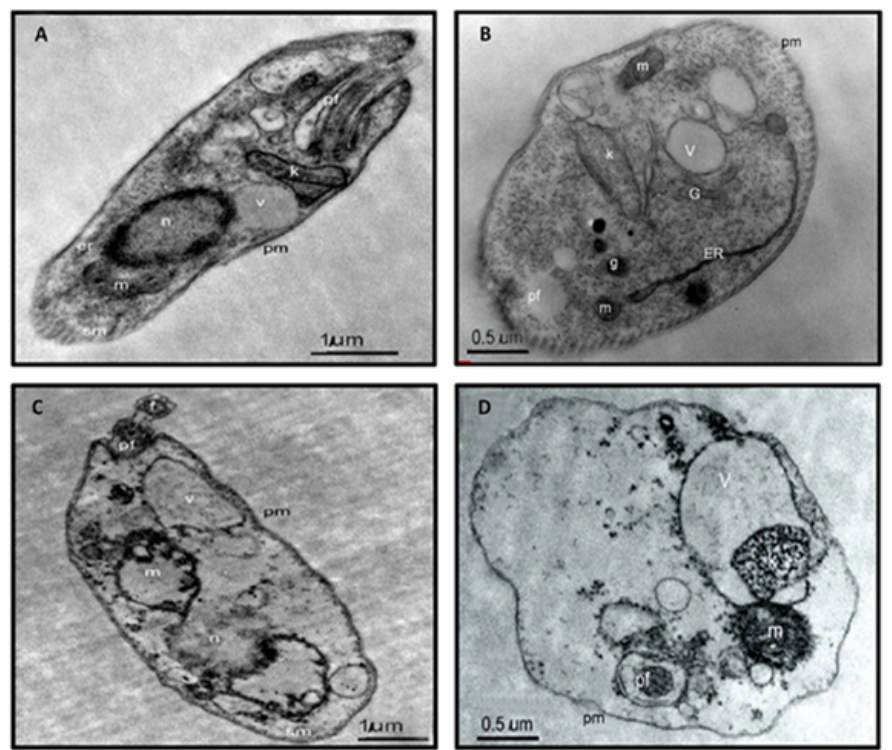

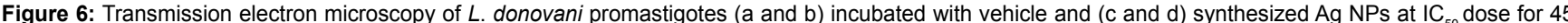
min, $\mathrm{n}$ : nucleus; k: kinetoplast; m: mitrochondria; pf: pocket flagellar; pm: plasma membrane; G: golgi body; g: glycosome; ER: endoplasmic reticulum. Scale bars $1.0 \mu \mathrm{m}$ and $0.5 \mu \mathrm{m}$. 
after $24 \mathrm{~h}$ treatment. PI uptake was used to quantify the population of cells in which membrane integrity was lost resulting in cell death. Treated promastigotes undertaken PI in a concentration-dependent manner. Figure 7 shows sharp increase in PI positive (M2) cells from $19.27 \%$ at $12.5 \mu \mathrm{g} / \mathrm{mL}$ to $50.36 \%$ at $25 \mu \mathrm{g} / \mathrm{mL}$ and thereafter gradual decrease to $48.01 \%$ at $50 \mu \mathrm{g} / \mathrm{mL}$ after $24 \mathrm{~h}$ of treatment. Untreated cells which served as control showed no cell death. These results are consistent with those of other studies and suggested that the cytotoxic effect induced by biosynthesized Ag NPs involved apoptotic changes and the nuclear condensation was studied by the propidium iodide staining method [38].

\section{Cell cycle analysis}

To assess the role of different concentrations $(12.5,25$ and $50 \mu \mathrm{g} /$ $\mathrm{mL}$ ) of synthesized Ag NPs in mediating G0/G1 arrest and the present study performed cell cycle analysis by flow cytometry after PI staining of the parasites incubated for $24 \mathrm{~h}$, as described previously by us [39] Figure 8 shows that synthesized Ag NPs (at 12.5 and $25 \mu \mathrm{g} / \mathrm{mL}$ ) induced a marked increase in the number of cells in the G0/G1 phase (G1:48.69\% versus $60.50 \%$ to $62.00 \%$ ), and simultaneous decrease in both $S$ phase (S: $33.86 \%$ versus $31.73 \%$ to $27.70 \%$ ) and G2/M phase compared with control was observed (G2/M: $17.44 \%$ versus $7.76 \%$ to $10.30 \%)$. The concentration-dependent effect on G0/G1 arrest in promastigotes was largely at the expense of S phase cells, with low change in the G2/Mphase cell population compared with the untreated promastigotes. The drug-induced cell cycle perturbations, such as an increase in the number of cells in the G1 phase, have been reported to correlate with a response to chemotherapy [40].

\section{Analysis of externalized phosphatidylserine}

To delineate the nature of cell death, $L$. donovani promastigotes



$12.5 \mu \mathrm{g} / \mathrm{mL}$
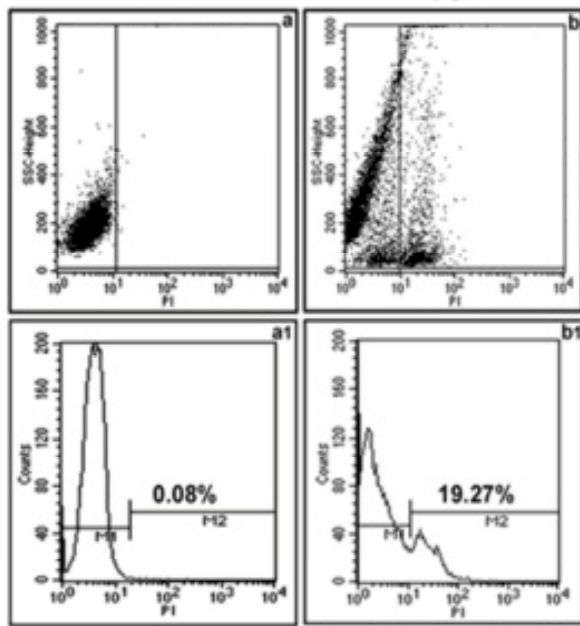

$25 \mu \mathrm{g} / \mathrm{mL}$
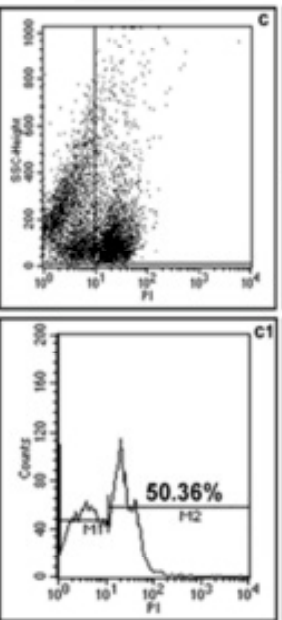

$50 \mu \mathrm{g} / \mathrm{mL}$
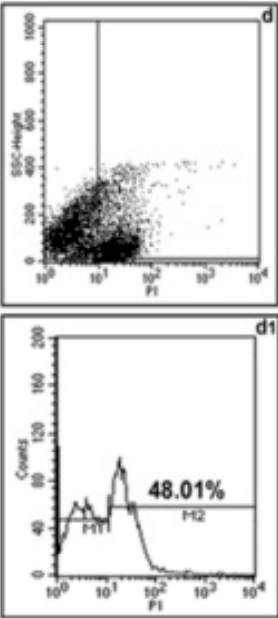

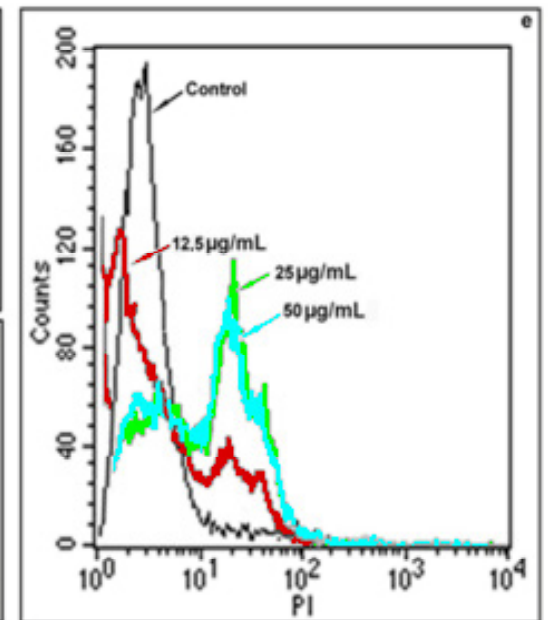

Figure 7: PI uptake analysis of $L$. donovani promastigotes treated with different concentrations of synthesized Ag NPs. Dot plots (a, b, $c$ and d) show that treatment of Leishmania parasites with synthesized Ag NPs leads to (PI-positive cells M2) (a1,b1,c1 and d1) cell death in a concentration-dependent manner.
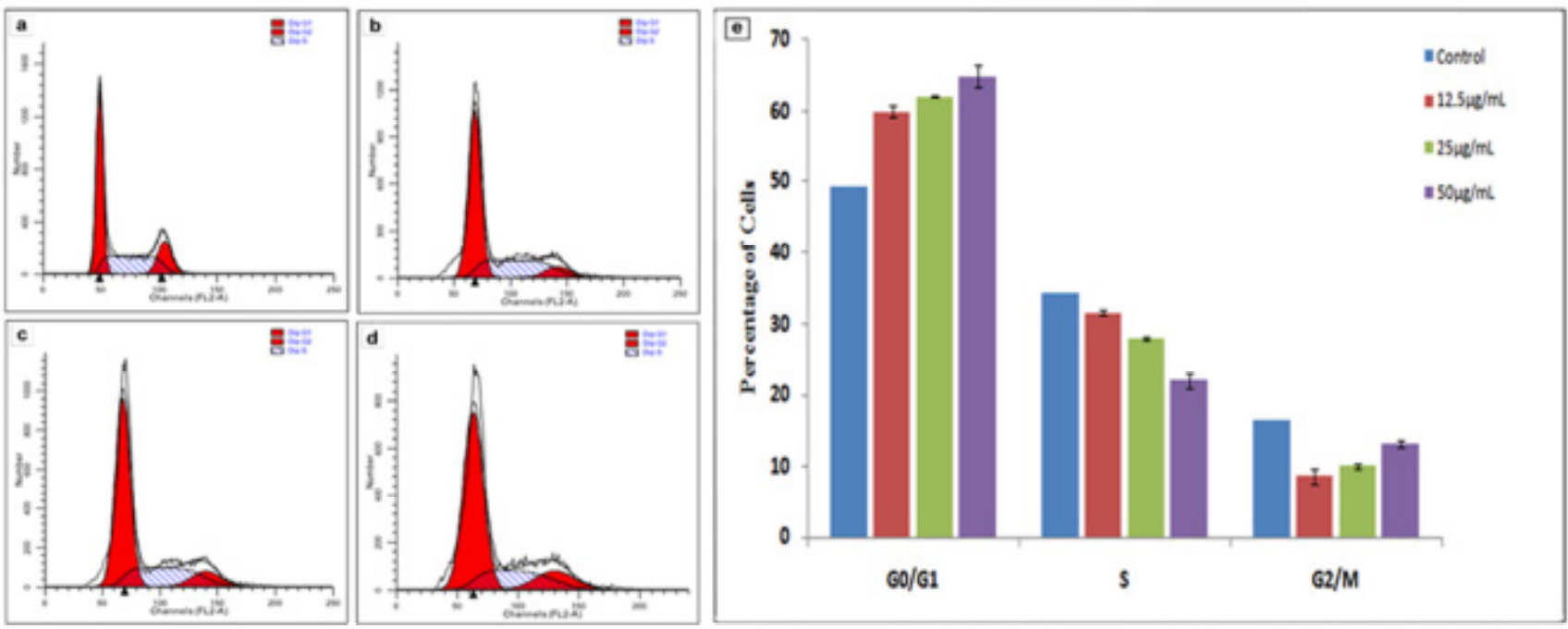

Figure 8: Synthesized Ag NPs induced cell cycle arrest in the G0/G1 phase of L. donovani parasites. After treatment with different concentrations of synthesized Ag NPs (a, b, c and d) for $24 \mathrm{~h}$, promastigotes were collected, washed with PBS and stained with PI, the DNA content was analysed by flow cytometry (e) Graph showing \% population in G0/G1, S and G2/M phase of parasites treated with different concentrations $(12.5,25$ and $50 \mu \mathrm{g} / \mathrm{mL})$ of synthesized Ag NPs. 

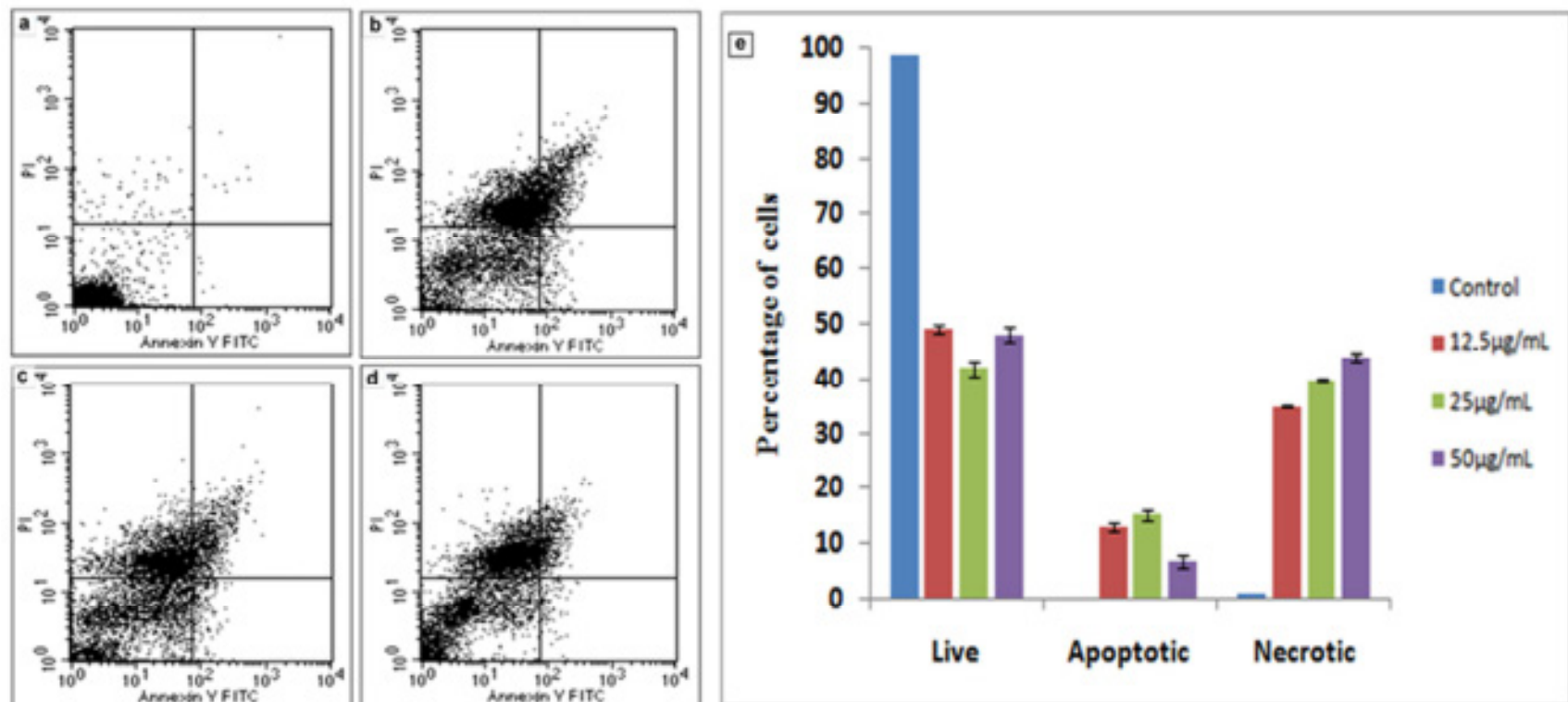

Figure 9: Externalization of phosphatidylserine in synthesized Ag NPs treated promastigotes. L. donovani promastigotes were incubated with different concentrations of synthesized Ag NPs (a) control (b) $12.5 \mu \mathrm{g} / \mathrm{mL}$ (c) $25 \mu \mathrm{g} / \mathrm{mL}$ (d) $50 \mu \mathrm{g} / \mathrm{mL}$ for $24 \mathrm{~h}$ and analysed by flow cytometry. After indicated incubation time, a significant number of membrane compromised cells were stained positively by annexin V- FITC, PI (upper-right quadrant) and only PI positive (upper-left quardrant) (e) Graph showing percentage population of live, apoptotic and necrotic state of parasites treated with different concentrations of synthesized Ag NPs.

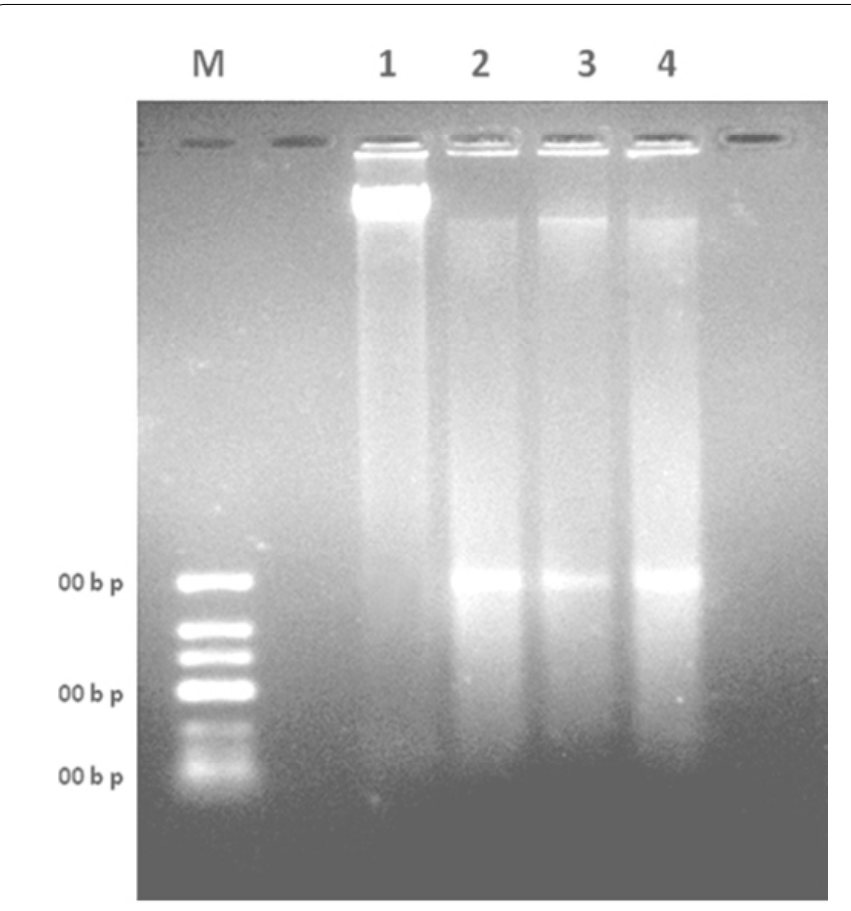

Figure 10: DNA fragmentation of $L$. donovani promastigotes treated with different concentrations of synthesized Ag NPs $(12.5,25$ and $50 \mu \mathrm{g} / \mathrm{mL})$. M represents DNA ladder, Lane 1 shows DNA from untreated cells while Lane 2 , 3 and 4 represent DNA from synthesized Ag NPs treated cells.

which were treated with different concentrations $(12.5,25$ and $50 \mu \mathrm{g} /$ $\mathrm{mL}$ ) of synthesized Ag NPs for $24 \mathrm{~h}$ were harvested, washed with PBS and double-stained with annexin V-FITC and PI. The number of cells that were PI-positive (upper-left quadrant) gradually increased from $34.87,39.90$ and $44.01 \%$ at $12.5,25$ and $50 \mu \mathrm{g} / \mathrm{mL}$, respectively. These observations suggested that synthesized Ag NPs induced cell death by necrosis. The synthesized Ag NPs treated promastigotes showed positive for both annexin $\mathrm{V}$ and PI-positive (upper-right quadrant) and decreased the activity of $13.12,15.17$ and $6.78 \%$ at $12.5,25$ and $50 \mu \mathrm{g} /$ $\mathrm{mL}$, respectively (Figure 9). In contrast, only $0.18 \%$ of untreated cells, which served as control were annexin V and PI-positive and showed no cell death. These results are a confirmatory indication of shift from apoptosis to necrosis on treatment of $L$. donovani promastigotes with synthesized Ag NPs. Fluorescein-conjugated annexin-V was used to detect externalized phosphatidylserine as it has a high binding affinity to this phospholipid component. Annexin- $\mathrm{V}$ showed the percentage of apoptotic, necrotic and surviving cells. Khademvatan et al. [41] reported that the Annexin V- FLUOS staining induced apoptotic phenomenon in promastigotes of Leishmania major using FACS flow cytometry.

\section{DNA fragmentation assay}

Treatment of promastigotes with different concentrations (12.5, 25 and $50 \mu \mathrm{g} / \mathrm{mL}$ ) of synthesized Ag NPs for $24 \mathrm{~h}$ and revealed DNA breakage which was not extensive. High molecular weight DNA fragments $\sim 700$ bp were observed (Figure 10), which reconfirmed that mode of cell death in promastigotes may be largely due to necrosis. In the present study, synthesized Ag NPs using the aqueous leaves extracts of E. prostrata for $24 \mathrm{~h}$, revealed DNA breakage which was not extensive. Previous reports showed that the Ag NPs were found to increase the DNA tail length in a comet assay, which measures DNA strand breaks as well as alkali labile sites [42].

\section{Formation of ROS in L. donovani}

An inherent basic level of ROS production in wild type promastigotes was detected with mean florescence intensity of $82.66 \%$. Treatment of promastigotes with synthesized Ag NPs for $24 \mathrm{~h}$ revealed a gradual decrease in ROS generation from $34.35,30.42$ and $27.96 \%$ at 12.5, 25 and $50 \mu \mathrm{g} / \mathrm{mL}$, respectively with respect to control cells (Figure 11). However, the present study showed the decreased ROS production 
in the synthesized Ag NPs treated parasites which was responsible for caspase independent necrotic cell death mechanism. An established event in most apoptotic cells was the generation of ROS in the cytosol, which directs the cell and its neighboring cells towards the path of apoptotic cell death [43]. Lower levels of ROS in our study could be a result of the antioxidant activity of the aqueous leaves extract of $E$. prostrata which constituted the synthesized Ag NPs. Presumably this effect resulted in a shift from apoptosis to G0/G1 arrest followed by necrotic cell death in $L$. donovani.

\section{Measurement of intracellular non-protein thiols}

The fluorescent probe, 5-chloromethyl fluorescein diacetate was used to measure total intracellular non-protein thiols after treatment of $L$. donovani promastigotes with aqueous leaves extract of $E$. prostrata, synthesized Ag NPs and $\mathrm{AgNO}_{3}$ solution. Synthesized $\mathrm{Ag}$ NPs showed remarkable decrease $(3.55 \%)$ in comparison with the control cells $(219.69 \%)$ at $24 \mathrm{~h}$. On analysis of our results we found that intracellular non protein thiols increase $(261.16 \%)$ in comparison with the wild type cells $(219.69 \%)$ was presumably a result of the antioxidant activity of the aqueous leaves extract of E. prostrata. Also, Ag was known to be an excellent effective Trypanothione reductase (TR) inhibitor. In the present observations, $\mathrm{AgNO}_{3}$ treated cells were obtained a remarkable decrease $(5.67 \%)$ in comparison with the wild type cells (219.69\%) (Figure 12). The glutathione/glutathione reductase a

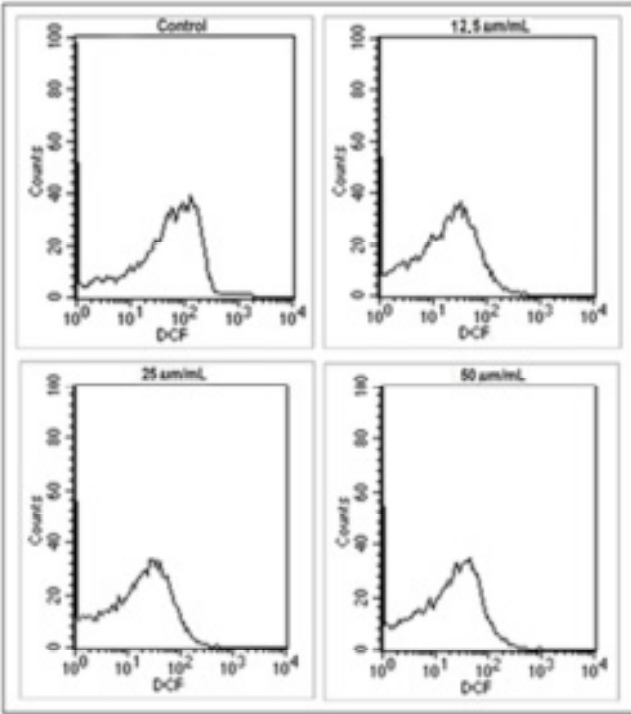

b

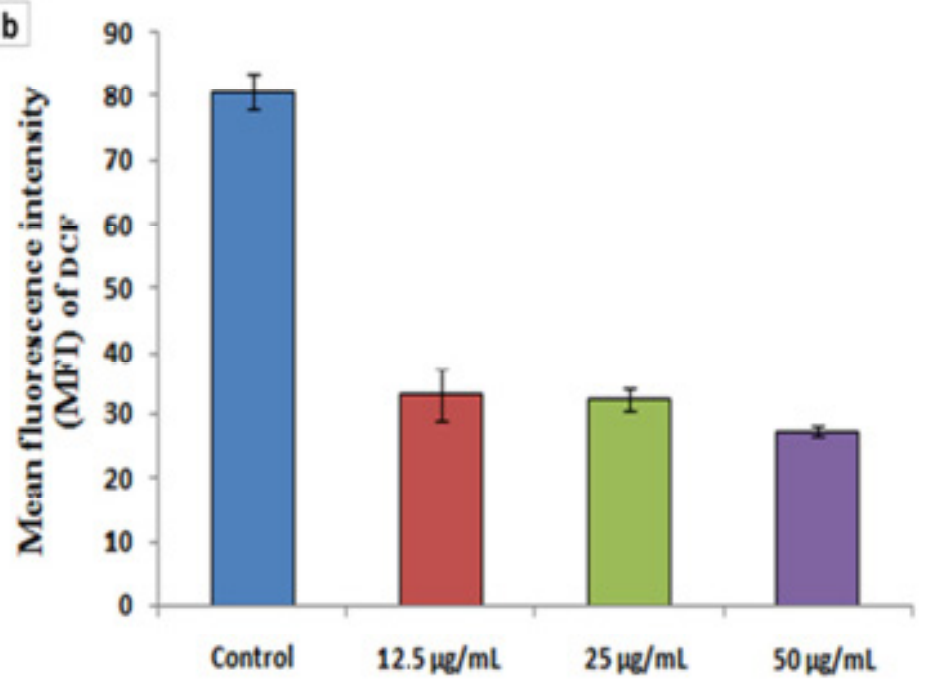

Figure 11: ROS generation was measured using the fluorescent dye 2,7 dichlorodihydrofluorescein diacetate after treatment with (a) different concentrations (12.5, 25 and $50 \mu \mathrm{g} / \mathrm{mL}$ ) of synthesized Ag NPs for $24 \mathrm{~h}$ and its fluorescence was measured using a flow cytometer (b) Graph shows mean fluorescence intensity of DCF in control and synthesized Ag NPs treated cells at $24 \mathrm{~h}$.

a
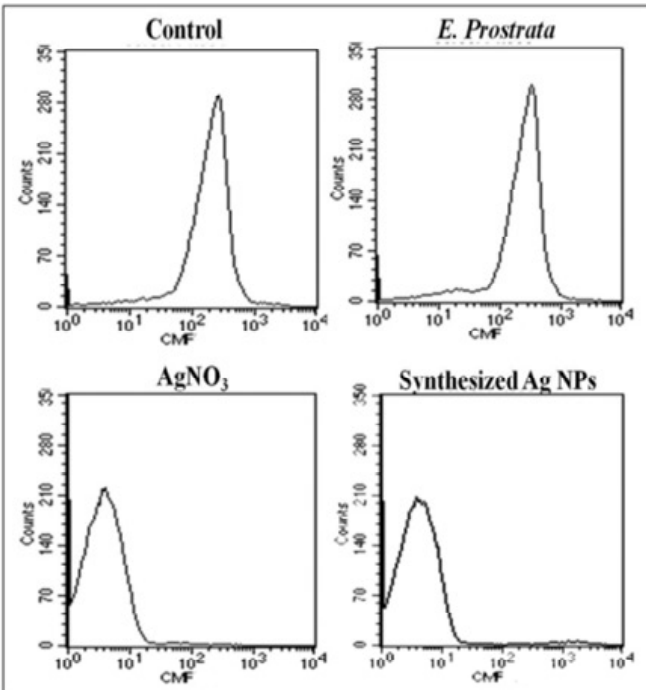

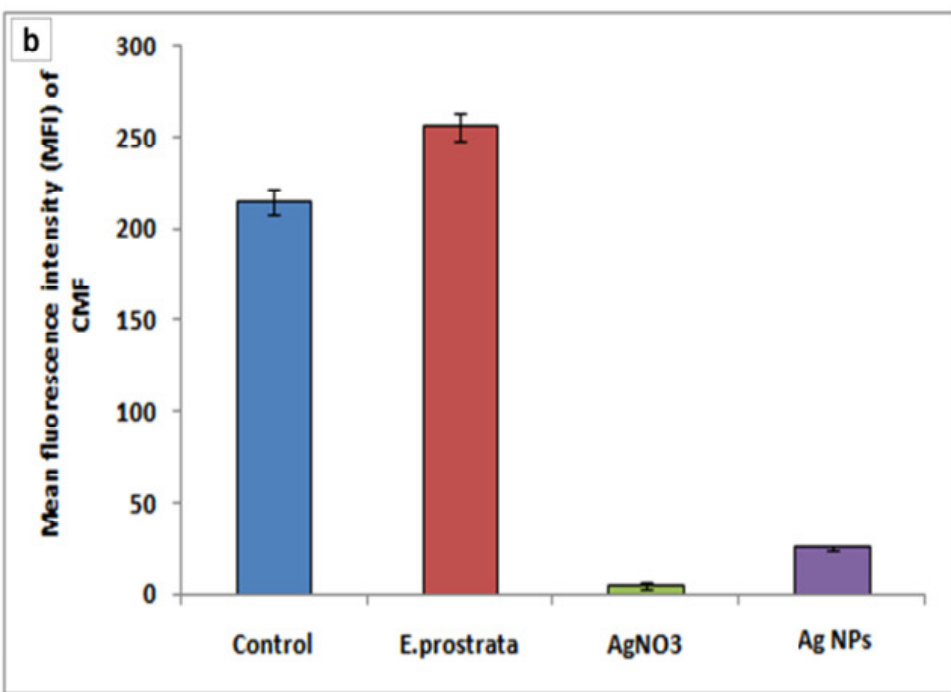

Figure 12: (a) Intracellular level of the glutathione (GSH) in L. donovani promastigotes treated with E. prostrata, $\mathrm{AgNO}_{3}$ solution and synthesized Ag NPs (b) Graph shows mean fluorescence intensity of CMF (GSH sensitive probe) in control, E. prostrata, $\mathrm{AgNO}_{3}$ and synthesized Ag NPs treated cells at $24 \mathrm{~h}$. The data are presented as means \pm standard deviation of three independent experiments. 
Citation: Zahir AA, Chauhan IS, Bagavan A, Kamaraj C, Elango G, et al. (2014) Synthesis of Nanoparticles Using Euphorbia prostrata Extract Reveals a Shift from Apoptosis to G0/G1 Arrest in Leishmania donovani. J Nanomed Nanotechnol 5: 213. doi: 10.4172/2157-7439.1000213

eukaryotic redox system was replaced by the unique TR system against L. donovani. Earlier authors reported that the Ag NPs was known to be an excellent effective TR inhibitor [44]. This was also corroborated by our results which showed maximum TR inhibition in synthesized Ag NPs treated promastigotes in comparison to aqueous leaves extract of E. prostrata treated promastigotes. It has been established that 2,3-dihydrobenzofuran, the main chemical constituent of plant extract of E. prostrata was also a promising antileishmanial lead molecule and contains antitubulin properties [45]. This drug target of the parasite has a different primary amino acid sequence to that of its host. The depletion of intracellular non-protein thiols in Leishmania parasites treated with synthesized Ag NPs was independent of ROS generation. Our study therefore shows the important benefit of taking up these synthesized Ag NPs further for clinical development as our green synthesized NPs has advantage of prevention of development of drug resistance.

\section{Conclusions}

The present finding revealed that the aqueous leaves extracts of $E$. prostrata are capable of synthesizing NPs from inorganic salts would also provide a clue as to one of the probable ways by which the drug may act inside the living systems. Thus, it seems quite possible that if we extrapolate the results of the present investigation, the leaves extracts of E. prostrata may also be capable of synthesizing NPs from some inorganic salts available in the living system and which in turn could have some role in eliciting the medicinal responses to remove the disease/disease symptoms. The results are very promising since the extract promotes the formation of NPs at room temperature with a fast kinetics and with no harmful chemicals. In conclusion, this study affirm from our studies that the synthesized Ag NPs were potent active against promastigotes of $L$. donovani compared with $\mathrm{TiO}_{2} \mathrm{NPs}$, aqueous leaves extracts and bulk solutions. The potent leishmanicidal effect of the active synthesized Ag NPs from the aqueous leaves extract may provide promising leads for the development of new and safer drugs against visceral leishmaniasis in near future.

\section{Acknowledgments}

The authors are grateful to C. Abdul Hakeem College Management, Dr. K. Masood Ahmed Principal, and Dr. Hameed Abdul Razack, Head of Zoology Department for providing the facilities to carry out this work. The technical assistance of Mr. A.L. Vishwakarma regarding flow cytometry is acknowledged. This work was supported by Council of Scientific and Industrial Research (CSIR) funded network project "Host Interactome analysis: Understanding the Role of Host molecules in Parasitic Infection (HOPE)."

This is CDRI communication no. 80/2014/NS.

\section{References}

1. http://www.who.int/leishmaniasis.disease_epidemiology/en/index.html

2. Richard JV, Werbovetz KA (2010) New antileishmanial candidates and lead compounds. Curr Opin Chem Biol 14: 447-455.

3. Ezra N, Ochoa MT, Craft N (2010) Human immunodeficiency virus and leishmaniasis. J Glob Infect Dis 2: 248-257.

4. Kim BY, Rutka JT, Chan WC (2010) Nanomedicine. N Engl J Med 363: 24342443.

5. Irache JM, Esparza I, Gamazo C, Agüeros M, Espuelas S (2011) Nanomedicine: novel approaches in human and veterinary therapeutics. Vet Parasitol 180: 47 71.

6. Morones JR, Elechiguerra JL, Camacho A, Holt K, Kouri JB, et al. (2005) The bactericidal effect of silver nanoparticles. Nanotechnology 16: 2346-2353.

7. Sinha S, Pan I, Chanda P, Sen SK (2009) Nanoparticles fabrication using ambient biological resources. J Appl Biosci 19: 1113-1130.

8. Bhainsa KC1, D'Souza SF (2006) Extracellular biosynthesis of silver nanoparticles using the fungus Aspergillus fumigatus. Colloids Surf B Biointerfaces 47: 160-164.
9. Mohebali M, Rezayat MM, Gilani K, Sarkar S, Akhoundi B, et al. (2009) Nanosilver in the treatment of localized cutaneous leishmaniasis caused by Leishmania major (MRHO/IR/75/ER): an in vitro and in vivo study. J Pharmaceutical Sci 17: 285-289.

10. Zampa MF, Araújo IM, Costa V, Nery Costa CH, Santos JR Jr, et al. (2009) Leishmanicidal activity and immobilization of dermaseptin 01 antimicrobial peptides in ultrathin films for nanomedicine applications. Nanomedicine 5: 352 358

11. Allahverdiyev AM, Abamor ES, Bagirova M, Ustundag CB, Kaya C, et al. (2011) Antileishmanial effect of silver nanoparticles and their enhanced antiparasitic activity under ultraviolet light. Int J Nanomed 6: 2705-2714.

12. Torabi N, Mohebali M, Shahverdi AR, Rezayat SM, Edrissian GH, et al. (2011) Nanogold for the treatment of zoonotic cutaneous leishmaniasis caused by Leishmania major (MRHO/IR/75/ER): an animal trial with methanol extract of Eucalyptus camaldulensis. J Pharmaceutical Health Sci 1: 13-16.

13. Navarro L, Dunoyer P, Jay F, Arnold B, Dharmasiri N, et al. (2006) A plant miRNA contributes to antibacterial resistance by repressing auxin signaling Science 312: 436-439

14. Wiesenthal A, Hunter L, Wang S, Wickliffe J, Wilkerson M (2011) Nanoparticles: small and mighty. Int J Dermatol 50: 247-254.

15. Das S, Roy P, Mondal S, Bera T, Mukherjee A (2013) One pot synthesis of gold nanoparticles and application in chemotherapy of wild and resistant type visceral leishmaniasis. Colloids Surf B Biointerfaces 107: 27-34.

16. Sundrarajan M, Gowri S (2011) Green synthesis of titanium dioxide nanoparticles by Nyctanthes arbor-tristis leaves extract. Chalcogenide Lett 8 : 447-451.

17. Schmelzer GH, Gurib-Fakim A (2008) Plant resources of tropical Africa medicinal plants 1, Backhuys publishers, Netherlands, 287.

18. Kamgang R, Hortense GK, Pascal W (2007) Activity of aqueous ethanol extract of Euphorbia prostrata ait on Shigella dysenteriae type 1- induced diarrhea in rats. Indian J Pharmacol 39: 240-244.

19. Kerboeuf D, Riou M, Guégnard F (2008) Flavonoids and related compounds in parasitic disease control. Mini Rev Med Chem 8: 116-128.

20. Radtke OA, Foo LY, Lu Y, Kiderlen AF, Kolodziej H (2003) Evaluation of sage phenolics for their antileishmanial activity and modulatory effects on interleukin-6, interferon and tumour necrosis factor-alpha-release in RAW 264.7 cells. Z Naturforsch C 58: 395-400.

21. Sharma U, Singh D, Kumar P, Dobhal MP, Singh S (2011) Antiparasitic activity of plumericin \& isoplumericin isolated from Plumeria bicolor against Leishmania donovani. Indian J Med Res 134: 709-716.

22. Parashar UK, Saxena PS, Srivastava A (2009) Bioinspired synthesis of silver nanoparticles. Dig J Nanomater Biostruct 4: 159-166.

23. Veerasamy R, Xin TZ, Gunasagaran S, Xiang TFW, Yang EFC, et al. (2011) Biosynthesis of silver nanoparticles using mangosteen leaf extract and evaluation of their antimicrobial activities. Saudi Chem Soc 15: 113-120.

24. Horcas I, Fernández R, Gómez-Rodríguez JM, Colchero J, Gómez-Herrero J, et al. (2007) WSXM: a software for scanning probe microscopy and a tool for nanotechnology. Rev Sci Instrum 78: 013705.

25. Suresh C, Senthilkumar S, Vijayakumari K (2012) GC-MS analysis of Tephrosia purpurea pers leaf extract- traditional valuable plant. Int J Uni Pharm Life Sci 2: 86-91.

26. Kaur J, Sundar S, Singh N (2010) Molecular docking, structure - activity relationship and biologic evaluation of the anticancer drug monastrol as a pteridine reductase inhibitor in a clinical isolate of Leishmania donovani. J Antimicrob Chemother 65: 1742-1748.

27. Ghosh S, Debnath S, Hazra S, Hartung A, Thomale K, et al. (2011) Valeriana wallichii root extracts and fractions with activity against Leishmania spp. Parasitol Res 108: 861-871.

28. do Socorro S Rosa Mdo S, Mendonça-Filho RR, Bizzo HR, de Almeida Rodrigues I, Soares RM, et al. (2003) Antileishmanial activity of a linalool-rich essential oil from Croton cajucara. Antimicrob Agents Chemother 47: 18951901.

29. Kaur J, Singh BK, Tripathi RP, Singh P, Singh N (2009) Leishmania donovani: a glycosyl dihydropyridine analogue induces apoptosis like cell death via targeting pteridine reductase 1 in promastigotes. Exp Parasitol 123: 258-264. 
Citation: Zahir AA, Chauhan IS, Bagavan A, Kamaraj C, Elango G, et al. (2014) Synthesis of Nanoparticles Using Euphorbia prostrata Extract Reveals a Shift from Apoptosis to G0/G1 Arrest in Leishmania donovani. J Nanomed Nanotechnol 5: 213. doi: 10.4172/2157-7439.1000213

30. Mukherjee SB, Das M, Sudhandiran G, Shaha C (2002) Increase in cytosolic $\mathrm{Ca}^{2+}$ levels through the activation of non-selective cation channels induced by oxidative stress causes mitochondrial depolarization leading to apoptosis-like death in Leishmania donovani promastigotes. J Biol Chem 277: 24717-24727.

31. Sarkar A, Mandal G, Singh N, Sundar S, Chatterjee M (2009) Flow cytometric determination of intracellular non-protein thiols in Leishmania promastigotes using 5-chloromethyl fluorescein diacetate. Exp Parasitol 122: 299-305.

32. Dubey M, Bhadauria S, Kushwah BS (2009) Green synthesis of nanosilver particles from extract of Eucalyptus hybrida (safeda) leaf. Dig J Nanomater Biostruct 4: 537-543

33. Liu Z, Hong L, Guo B (2005) Physicochemical and electrochemical characterization of anatase titanium dioxide NPs. J Power Sources 143: 231235.

34. Coates J (2000) In: Meyers RA (edn) Interpretation of infrared spectra, a practical approach. Encyclopedia of analytical chemistry. Wiley, Chichester, 10815-10837.

35. Logeswari P, Silambarasan S, Abraham J (2012) Synthesis of silve nanoparticles using plants extract and analysis of their antimicrobial property. J Saudi Chem Soc.

36. Van Miert S, Van Dyck S, Schmidt TJ, Brun R, Vlietinck A, et al. (2005) Antileishmanial activity, cytotoxicity and QSAR analysis of synthetic dihydrobenzofuran lignans and related benzofurans. Bioorg Med Chem 13: 661-669

37. AshaRani PV, Low Kah Mun G, Hande MP, Valiyaveettil S (2009) Cytotoxicity and genotoxicity of silver nanoparticles in human cells. ACS Nano 3: 279-290.
38. Prabhu D, Arulvasu C, Babu G, Manikandan R, Srinivasan P (2013) Biologically synthesized green silver nanoparticles from leaf extract of Vitex negundo $L$. induce growth-inhibitory effect on human colon cancer cell line HCT15. Process Biochem. 48: 317-324

39. Kaur J, Dutta S, Chang KP, Singh N (2013) A member of the Ras oncogene family, RAP1A, mediates antileishmanial activity of monastrol. J Antimicrob Chemother 68: 1071-1080.

40. Efuet ET, Keyomarsi K (2006) Farnesyl and geranylgeranyl transferase inhibitors induce $\mathrm{G} 1$ arrest by targeting the proteasome. Cancer Res 66: 10401051.

41. Khademvatan S, Saki J, Gharavi MJ, Rahim F (2011) Allium sativum extract induces apoptosis in Leishmania major. J Med Plants Res 5: 3725-3732.

42. Premanathan M, Karthikeyan K, Jeyasubramanian K, Manivannan G (2011) Selective toxicity of $\mathrm{ZnO}$ nanoparticles toward Gram-positive bacteria and cancer cells by apoptosis through lipid peroxidation. Nanomed: Nanotechnol Biol Med 7: 184-192.

43. Chipuk JE, Green DR (2005) Do inducers of apoptosis trigger caspaseindependent cell death? Nat Rev Mol Cell Biol 6: 268-275.

44. Baiocco P, Ilari A1, Ceci P1, Orsini S2, Gramiccia M2, et al. (2010) Inhibitory Effect of Silver Nanoparticles on Trypanothione Reductase Activity and Leishmania infantum Proliferation. ACS Med Chem Lett 2: 230-233.

45. Van Miert S, Van Dyck S, Schmidt TJ, Brun R, Vlietinck A, et al. (2005) Antileishmanial activity, cytotoxicity and QSAR analysis of synthetic dihydrobenzofuran lignans and related benzofurans. Bioorg Med Chem 13 661-669. 